\title{
PENERAPAN MODEL INKUIRI TERBIMBING BERBASIS FENOMENA ALAM UNTUK MENINGKATKAN KEMAMPUAN BERFIKIR KRITIS SISWA KELAS II SDN 4 KEDUNGGEBANG BANYUWANGI
}

\author{
Dalilatul Kasanah ${ }^{1}$, Moh Luqman Hakim ${ }^{2}$ \\ SDN 4 KedungGebang . Kec.Tegaldíimo, Kab. Banyuwangi \\ Program Studi PGSD Fakultas Ilmu Pendidikan Universitas Trunojoyo Madura
}

\begin{abstract}
The purpose of this study is: to describe the increase in critical thinking of second grade students SDN 4 Kedunggebang, Tegaldlimo, Banyuwangi through the implementation of guided inquiry learning models based on phenomena. This type of research is classroom action research consisting of 2 cycles, each of which consists of 2 meetings. To collect data, tests were used in each cycle and observation sheet. The data analysis techniques used are descriptive qualitative and quantitative data analysis techniques. The results of the research in each cycle showed that the level of critical thinking skills of students had increased, this was seen after the application of guided inquiry learning models based on phenomena, seen in cycle I increased to an average of 65, while in cycle II it has reached the completeness indicator which is an average of 90. This shows that students' critical thinking skills increase after the application of guided inquiry learning models based phenomena
\end{abstract}

Keywords: Guided Inquiry, Critical Thinking, Action Research

\begin{abstract}
ABSTRAK
Tujuan penelitian ini meliputi: (1) untuk mendeskripsikan peningkatan berfikir kritis siswa kelas II SDN 4 Kedunggebang Kec.Tegald́limo, Kab. Banyuwangi. melalui penerapan model pembelajaran inkuiri terbimbing berbasis fenomena alam. Jenis Penelitian ini adalah penelitian tindakan kelas yang terdiri 2 siklus yang masing-masing siklus terdiri dari 2 pertemuan. Untuk menghimpun data, digunakan tes pada setiap siklus dan lembar observasi. Adapun teknik analisis data yang digunakan yaitu dengan teknik analisis data deskriptif kualitatif dan kuantitatif. Hasil penelitian pada setiap siklus menunjukkan bahwa tingkat kemampuan berfikir kritis siswa mengalami peningkatan, hal ini terlihat setelah penerapan model pembelajaran inkuiri terbimbing berbasis fenomena alam, terlihat pada siklus 1 meningkat menjadi rata-rata 65 dengan ketuntasan klasikal sebesar 50\%; sedangkan pada siklus 2 telah mencapai indikator ketuntasan yaitu rata-rata 90 dengan ketuntasan klasikal sebesar $100 \%$. Hal ini menunjukkan bahwa kemampuan berfikir kritis siswa meningkat setelah penerapan model pembelajaran inkuiri terbimbing berbasis fenomena alam.
\end{abstract}

Kata Kunci: Inkuiri Termbimbing, Berfikir Kritis, Penelitian Tindakan Kelas

\footnotetext{
${ }^{1)}$ Korespondensi : Dalilatul Kasanah, SDN 4 Kedunggebang . Kec.Tegaldílimo, Kab. Banyuwangi Email : dalilatul.yakub@gmail.com

${ }^{2)}$ Korespondensi : Moh Luqman Hakim, Program Studi PGSD Fakultas Ilmu Pendidikan Universitas Trunojoyo Madura Email : luqmanhyacob@gmail.com
} 


\section{PENDAHULUAN}

Kehidupan masyarakat maju telah menuntut berbagai perubahan mendasar pada bidang pendidikan. Mulyasa (2013) menyatakan, untuk melaksanakan perubahan dalam bidang pendidikan tersebut, sejak tahun 1998, UNESCO telah mengemukakan dua basis landasan yaitu:

1. Pendidikan harus diletakan pada empat pilar belajar yaitu mengetahui (learning to know), belajar melakukan (learning to do), belajar hidup dalam kebersamaan (learning to live together), dan belajar menjadi diri sendiri (learning to be)

2. 2. Belajar seumur hidup (live to long).

Di Indonesia, terdapat beberapa upaya yang telah dilakukan oleh para pelaku pendidikan sebagai upaya untuk meningkatkan mutu pendidikan. Upayaupaya tersebut antara lain: Perubahan kurikulum, Aplikasi model pembelajaran yang disadur dari negara maju, peningkatan keefektifan bahan ajar, dan penambahan fasilitas pembelajaran

Sagala (2011: 4), menyatakan bahwa pendidikan merupakan suatu proses dalam rangka mempengaruhi siswa supaya mampu menyesuaikan diri sebaik mungkin dengan lingkungannya dan yang akan menimbulkan perubahan pada dirinya yang memungkinkan, sehingga berfungsi sesuai kompetensinya dalam kehidupan masyarakat.

Guru harus dapat mengadakan perubahan, dari kelas yang membosankan menjadi kelas yang menyenangkan (Rakhmat (2006: 213). Lahirnya generasi baru yang cerdas dan handal adalah suatu harapan bagi suatu bangsa, guru serta orang tua. Seperti yang tercermin dalam nilai-nilai mata pelajaran di kelas 2 SD bahwa masa depan bangsa ditentukan oleh generasi muda yang cerdas.

Berbicara tentang komponen pendidikan seperti pendidik, peserta didik, sarana dan prasarana dan hal - hal lainnya mengingatkan kita bahwa komponen tersebut merupakan faktor yang sangat berpengaruh sekali terhadap berjalan atau tidaknya, maju atau tidaknya suatu pendidikan. Hal ini sejalan dengan pernyataan Ngalim, Purwanto (1986:106) bahwa faktor-faktor yang mempengaruhi pendidikan diantaranya kematangan, intelejensi (kecerdasan), latihan dan ulangan, motivasi, sifat-sifat pribadi seseorang, keadaan keluarga, guru dan cara mengajar, alat-alat pelajaran,motivasi sosial dan lingkungan.

Berdasarkan hasil pengamatan dikelas ditemukan rendahnya kemampuan 
berfikir kritis siswa kelas II SDN 4 Kedunggebang Kec.Tegaldíimo, Kab. Banyuwangi hal ini terbukti berdasarkan data yang didapat dari hasil ulangan pada tema 1 semester ganjil tahun 2018- 2019 ternyata dari 10 siswa, tidak ada siswa yang nilai mencapai KKM yang ditetepkan sekolah. Dalam hal tersebut disebabkan oleh kurangnya motivasi belajar siswa, ini terlihat pada saat pembelajaran berlangsung, pada saat mengikuti pembelajaran siswa nampak tidak serius dan bersifat pasif, siswa lebih banyak mengobrol dengan teman sebangkunya dan berjalan- jalan saat pembelajaran berlangsung dari pada mendengarkan penjelasan guru.

Guru dapat memberikan kemudahan untuk mengatasi permasalahan ini. Salah satu yang digunakan adalah dengan memotivasi belajar siswa melalui pembelajaran yang menarik dengan memberi kesempatan pada siswa untuk menemukan atau menerapkan ide-ide mereka sendiri, dan mengajar siswa menjadi sadar dan secara sadar menggunakan strategi mereka sendiri untuk belajar. Guru dapat memberi siswa anak tangga yang membawa mereka ke pemahaman yang lebih tinggi, dengan catatan siswa sendiri yang harus memanjat anak tangga tersebut. Hamalik (2006) menyatakan guru dapat memberi bantuan kepada siswa agar mereka mampu menemukan masalahnya sendiri dan mencari solusi dari masalah tersebut pada saat pembelajaran. Bagi siswa, pembelajaran harus bergeser dari "diberi tahu" menjadi "aktif mencari tahu". Siswa harus didorong sebagai "penemu dan pemilik" ilmu, bukan sekedar pengguna atau penghafal pengetahuan.

Guru dapat menggunakan banyak model dalam menyampaikan materi pelajaran, salah satunya melalui inkuiri terbimbing. Menurut Vajoczki (2011) model pembelajaran inkuiri merupakan suatu model pembelajaran yang berorientasi pada proses dan keahlian untuk melakukan penelitian. Kuhlthau (2012) menyatakan bahwa inkuiri terbimbing dapat membantu siswa untuk berlatih dalam suatu tim, mengembangkan kompetensi dalam penelitian, pengetahuan, motivasi, kemampuan menulis, pembelajaran kooperatif dan keterampilan sosial. Siswa dapat menemukan konsep atau pengetahuan baru melalui proses hands-on activity yang terdapat pada model inkuiri terbimbing. Selain itu, siswa dapat dilatih untuk dapat memiliki karakter tanggung jawab dan disiplin pada saat kegiatan pengamatan berlangsung melalui inkuiri 
terbimbing,. Pentingnya pendidikan karakter pada siswa didukung oleh hasil penelitian Heckman, James \& Carneiro, Pedro (2003) yang menyimpulkan bahwa kecerdasan intelektual seseorang (verbal dan logis-matematis) hanya memberikan kontribusi $20 \%$ saja dari keberhasilan seseorang di masyarakat, sedangkan $80 \%$ lebih banyak ditentukan oleh kecerdasan emosi seseorang tersebut.

Penggunaan model pembelajaran inkuiri terbimbing dalam pembelajaran di sekolah telah banyak dilakukan, tentunya dengan hasil yang baik. Mao \& Chang (1999) menyatakan pembelajaran dengan model inkuiri dapat membantu siswa dalam mengembangkan keterampilan mental yang lebih tinggi, meningkatkan sikap mereka, memfasilitasi pembelajaran untuk meningkatkan konsep dan dapat meningkatkan tingkat prestasi mereka. Dengan meningkatnya prestasi belajar, hasil belajar siswa juga akan meningkat. Hal ini didukung dengan penelitian Greene (2003) dan Barron (2010) yang menyatakan hasil belajar siswa meningkat setelah menggunakan model inkuiri terbimbing dalam pembelajarannya. Selain itu, dengan menggunakan model pembelajaran inkuiri terbimbing, retensi siswa terhadap suatu materi menjadi jauh lebih lama (Vanags, Pammer \& Brinker. 2013).

Inkuiri terbimbing adalah suatu model pembelajaran yang siswa belajar suatu pengetahuan melalui aktivitas penyelidikan dari suatu masalah, isu-isu penting dan biasanya mempunyai jawaban yang lebih dari satu (Lee, Virginia, 2004). Schwarz \& Gwekwerere (2007) menyatakan inkuiri terbimbing adalah model pembelajaran yang di dalamnya terdapat beberapa kegiatan yang bersifat ilmiah. Dari kedua pendapat di atas, dapat diketahui bahwa model inkuiri terbimbing adalah suatu model pembelajaran yang didalamnya terdapat kegiatan ilmiah melalui aktivitas penyelidikan dari suatu masalah yang akan dipecahkan.

Kuhlthau (2012) menyatakan tahapan dalam pembelajaran dengan model inkuiri terbimbing dimulai dengan mengarahkan perhatian siswa untuk membuka sikap inkuiri, yaitu membuat mereka berfikir tentang penyelidikan yang akan dilakukan dan membantu mereka untuk menghubungkan peristiwa yang terjadi disekitar mereka. Tahapan tiap proses inkuiri terbimbing ditunjukkan pada Gambar 2.1. 


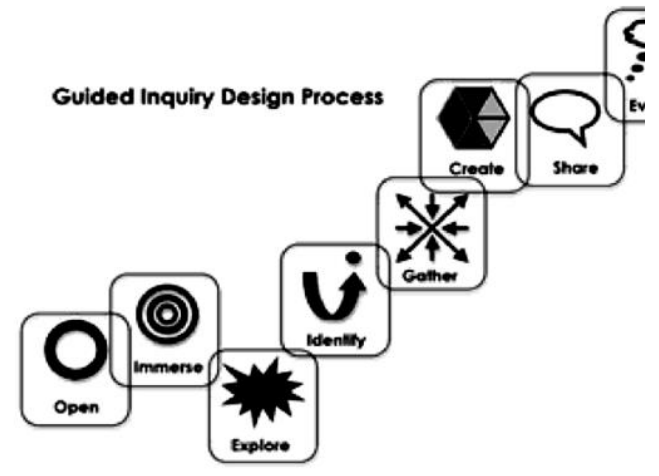

Gambar 1 Desain Proses Inkuiri Terbimbing (Kuhlthau, 2012)

Pada Gambar 1 diketahui bahwa proses inkuiri terbimbing dimulai dengan open yaitu mengajak siswa untuk melakukan penyelidikan selanjutnya diakhiri dengan tahapan evaluate. Kuhlthau (2012) menyatakan bahwa terdapat enam karakteristik inkuiri terbimbing (guided inquiry) yang meliputi:

1) Siswa belajar aktif dan terefleksikan pada pengalaman.

2) Siswa belajar berdasarkan pada apa yang mereka tahu.

3) Siswa mengembangkan rangkaian berfikir dalam proses pembelajaran melalui bimbingan. Rangkaian berpikir ke arah yang lebih tinggi memerlukan proses yang mendalam yang membawa kepada sebuah pemahaman. Proses yang mendalam memerlukan waktu dan motivasi yang dikembangkan oleh pertanyaanpertanyaan yang otentik mengenai objek yang telah digambarkan dari pengalaman dan keingintahuan siswa.

4) Perkembangan siswa terjadi secara bertahap.

5) Siswa belajar melalui interaksi sosial dengan orang lain.

Berdasarkan karakteristik tersebut, inkuiri terbimbing merupakan sebuah metode yang berfokus pada proses berpikir yang membangun pengalaman oleh keterlibatan siswa secara aktif dalam pembelajaran. Pendapat ini didukung oleh pendatat Kuhlthau (2012) yang menyatakan bahwa pada inkuiri terbimbing, guru difungsikan sebagai fasilitator.

$$
\text { Dengan dipadukannya }
$$
pembelajaran berbasis fenomena dengan model inkuiri diharapkan siswa tidak hanya berlatih secara ilmiah melalui proses inkuiri tetapi juga dapat melihat hubungan konsep dengan fenomena yang terjadi di sekitar mereka. Berikut sintak model inkuiri yang disisipkan dengan pembelajaran berbasis fenomena. 


\begin{tabular}{|c|c|}
\hline Tahap & Tingkah Laku Guru \\
\hline $\begin{array}{l}\text { Fase } 1 \\
\text { Orientasi siswa pada } \\
\text { fenomena }\end{array}$ & $\begin{array}{l}\text { - } \quad \text { Menyajikan permasalahan tentang fenomena fisika yang berhubungan dengan kalor. } \\
\text { - } \quad \text { Menjelaskan tujuan dan standar kompetensi yang akan dicapai. }\end{array}$ \\
\hline $\begin{array}{l}\text { Fase } 2 \\
\text { Merumusan rumusan } \\
\text { masalah dan hipotesis }\end{array}$ & $\begin{array}{l}\text { - } \quad \text { Guru memberi pertanyaan kepada siswa tentang rumusan masalah dan hipotesis yang tepat sesuai } \\
\text { dengan gambar fenomena yang tersaji pada fase } 1\end{array}$ \\
\hline $\begin{array}{l}\text { Fase } 3 \\
\text { Mengorganisasikan siswa } \\
\text { untuk memperoleh informasi }\end{array}$ & $\begin{array}{l}\text { - } \quad \text { Guru Membentuk siswa dalam kelompok yang setiap kelompok terdiri dari 4-5 orang. } \\
\text { - } \quad \text { Memberikan penjelasan mengenai hal-hal yang perlu diperhatikan dalam penyelidikan. }\end{array}$ \\
\hline $\begin{array}{l}\text { Fase } 4 \\
\text { Memproses informasi dengan } \\
\text { pelakukan penyelidikan }\end{array}$ & $\begin{array}{l}\text { - } \quad \text { Membimbing siswa dalam melakukan penyelidikan secara inkuiri melalui panduan LKS sampai siswa } \\
\text { dapat melakukan penyelidikan dan dapat menganalisis hasil penyelidikanya. }\end{array}$ \\
\hline $\begin{array}{l}\text { Fase } 5 \\
\text { Menganalisis hasil } \\
\text { penyelidikan dan Menyajikan } \\
\text { hasil penyelidikan }\end{array}$ & $\begin{array}{l}\text { - } \quad \text { Guru membimbing siswa untuk menganalisis hasil penyelidikan dengan cara membimbing siswa } \\
\text { untuk diskusi dan tanya jawab tentang hasil penyelidikan } \\
\text { - } \quad \text { Membimbing siswa untuk mempresentasikan hasil penyelidikanya. }\end{array}$ \\
\hline $\begin{array}{l}\text { Fase } 6 \\
\text { Menganalisis penjelasan } \\
\text { yang disajikan pada fase } 1\end{array}$ & $\begin{array}{l}\text { - } \quad \text { Guru meminta siswa menjelaskan hasil analisis fenomena yang disajikan pada fase } 1 \\
\text { - } \quad \text { Siswa ditugaskan untuk menghubungkan hasil analisisnya ke contoh fenomena lain disekitar mereka }\end{array}$ \\
\hline $\begin{array}{l}\text { Fase } 7 \\
\text { Evaluasi }\end{array}$ & $\begin{array}{l}\text { - } \quad \text { Guru mengevaluasi hasil pembelajaran serta memberi koreksi dan penguatan konsep. } \\
\text { - } \quad \text { Memberikan gambaran tentang penerapan konsep pada fenomena lain. } \\
\text { - } \quad \text { Guru memberikan tugas individu mengenai materi yang telah dipelajari. }\end{array}$ \\
\hline
\end{tabular}

\section{METODE PENELITIAN}

Jenis penelitain pada penelitian ini adalah penelitian tindakan kelas (Classroom Action Research). Penelitian tindakan kelas adalah penelitian dalam bidang pendidikan yang dilaksanakan dalam kelas dengan tujuan untuk memperbaiki dan meningkatkan kualitas pembelajaran. Dengan metode penelitian ini, diharapkan dapat memberikan gambaran tentang pembelajaran yang baik di dalam kelas. Dengan demikian proses belajar dapat berlangsung lebih efisien dan berorientasi pada peningkatan hasil belajar siswa pada materi yang disampaikan.
Pelaksanaan penelitian tindakan ini melalui beberapa tahapan yang berlangsung dalam bentuk siklus, yang dikembangkan berdasarkan desain PTK Model Kemmis \& McTaggart (dalam Depdiknas, 2003:18). Model ini memfokuskan empat tindakan dalam satu siklus kegiatan yang dilaksanakan secara berdaur ulang. Tindakan tersebut berupa: perencanaan tindakan, pelaksanaan tindakan, observasi tindakan, dan refleksi tindakan. Jika dalam satu siklus belum terjadi peningkatan yang signifikan, maka dipandang perlu untuk melakukan siklus lanjutan. 
Subjek penelitian ini adalah seluruh siswa kelas 2 SDN 4 Kedunggebang . Kec.Tegaldíimo, Kab. Banyuwangi. Penelitian ini di lakukan pada tanggal 15 dan 16 Oktober 2019 Penelitian ini adalah penelitian tindakan kelas( PTK). Penelitian tindakan kelas ini dapat dikatakan sebuah tindakan yang dilaksanakan oleh pendidik untuk merperbaiki permasalahan yang terdapat di dalam kelas agar kualitas hasil pembelajaran mencapai nilai diatas KKM. Untuk mengumpulkan data pada penelitian ini digunakan Tes kemampuan berfikir kritis siswa. Pada penelitian ini digunakan model Kemmis \& Mc. Taggart seperti pada gambar.

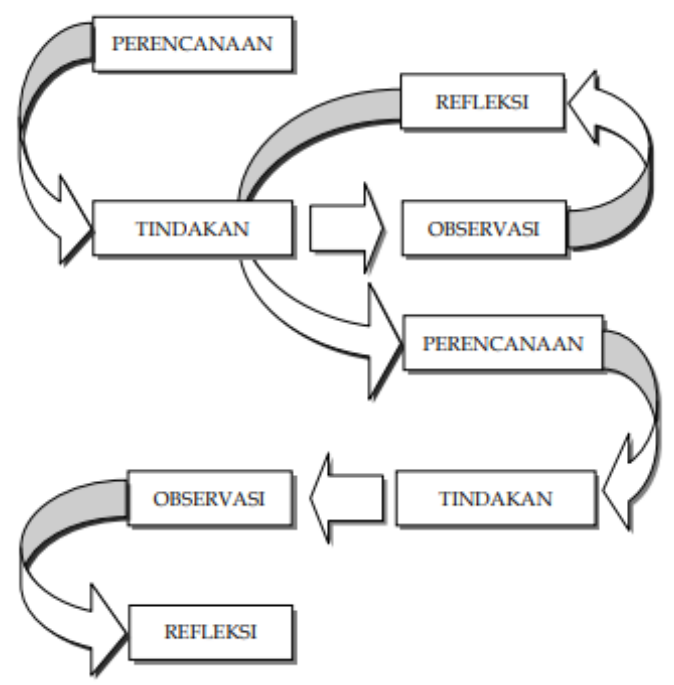

Gambar 2: Model Penelitian Tagart dan Kemmis

Model Kemmis \& Mc. Taggart bila dicermati hakekatnya berupa perangka tperangkat atau untaian-untaian dengan satu perangkat terdiri dari empat komponen yaitu perencanaan,tindakan, pengamatan dan refleksi. Untaian tersebut dipandang sebagai suatu siklus. Oleh karena itu pengertian siklus di sini adalah putaran kegiatan yang terdiri dari perencanaan, tindakan, observasi dan refleksi. Banyaknya siklus dalam penelitian tindakan kelas tergantung dari permasalahan yang perlu dipecahkan, semakin banyak permasalahan yang ingin dipecahkan semakin banyak pula siklus yang akan dilalui. Jika suatu penelitian tindakan kelas ingin mengkaitkan materi pelajaran dan kompetensi dasar dengan sendirinya jumlah siklus untuk setiap mata pelajaran melibatkan lebih dari dua siklus.(Depdiknas, 2005).

\section{HASIL DAN PEMBAHASAN}

\section{A. Siklus I}

Pelaksanaa siklus pertama diawali dengan kegiatan guru untuk memberikan apersepsi, motivasi, serta menanyakan kesiapan siswa untuk mengikuti pembelajaran. Setelah semuanya siap, maka dilanjutkan dengan kegiatan siswa untuk mengamati contoh-contoh peristiwa alam yang terjadi di lingkuang sekitar melalui media foto yang dibagikan oleh guru. Suasana pembelajaran semakin hidup dengan adanya tanya jawab antara 
siswa dengan guru tentang kebermaknaan sebuah berita. Selanjutnya guru menggiring siswa pada kegiatan inti pembelajaran dengan menyampaikan kompetensi dasar yang akan dicapai, tujuan pembelajaran, serta rencana kegiatan yang akan dilaksanakan pada pertemuan tersebut

Kegiatan selanjutnya adalah guru memberi pertanyaan kepada siswa tentang rumusan masalah dan hipotesis yang tepat sesuai dengan gambar fenomena yang tersaji pada fase 1. Untuk lebih dapat mengoptimalkan kegiatan pembelajaran, Guru membentuk siswa dalam kelompok yang setiap kelompok terdiri dari 3 orang dan selanjtnya memberikan penjelasan mengenai hal-hal yang perlu diperhatikan dalam penyelidikan.

Siswa diarahkan untuk melakukan penyelidikan secara inkuiri untuk melakukan penyelidikan melalui panduan LKS sampai siswa dapat melakukan penyelidikan dan dapat menganalisis hasil penyelidikanya.

Setelah siswa selesai melakukan penyelidikan, Guru membimbing siswa untuk menganalisis hasil penyelidikan dengan cara membimbing siswa untuk diskusi dan tanya jawab tentang hasil penyelidikan. Hal ini dilakukan untuk melatih siswa agar memiliki kemampuan berfikir kritis.

Hasil evaluasi siklus I dapat diketahui pada gambar 2 .

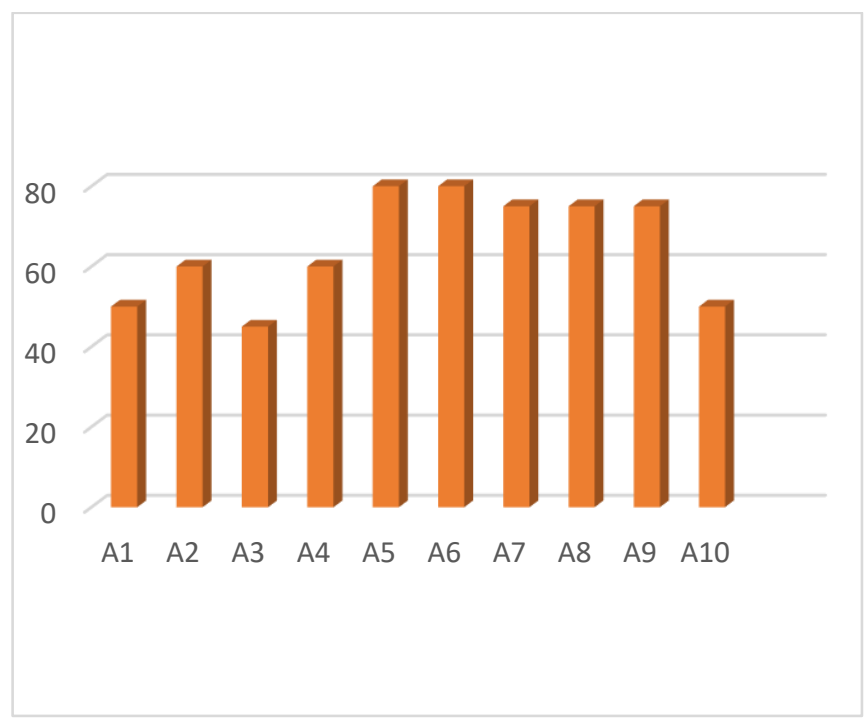

Gambar 3. Nilai kemampuan berfikir kritis siswa pada kelas I

\section{B. Siklus II}

Langkah-langkah kegiatan dalam perencanaan tindakan ini sama dengan yang dilakukan pada siklus I. Namun, ada beberapa tindakan tambahan yang perlu disesuaikan dengan hasil refleksi tindakan sebelumnya.

Pada siklus 2 ini, perbaikan yang dilakukan adalah dengan memberikan video fenomena alam. Kegiatan lain sama dengan kegiatan siklus I, namun pada saat siswa selesai melakukan penyelidikan, Guru membimbing dengan detail siswa untuk menganalisis hasil penyelidikan dengan cara membimbing siswa untuk 
diskusi dan tanya jawab tentang hasil penyelidikan. Hal ini dilakukan untuk melatih siswa agar memiliki kemampuan berfikir kritis lebih meningkat. Setelah selesai membimbing, guru menugaskan kelompok siswa untuk mempresentasikan hasil penyelidikanya dan menjelaskan hasil analisis fenomena yang disajikan pada fase 1. Pada tahap ini Siswa ditugaskan untuk menghubungkan hasil analisisnya ke contoh fenomena lain disekitar mereka

Secara keseluruhan hasil observasi terhadap aktivitas siswa selama pembelajaran dalam siklus II sudah baik. Terbukti dari delapan aspek yang dinilai, enam poin menunjukkan skor ideal. Hanya ada dua poin dengan skor 3 dan itu pun merupakan skor yang baik.

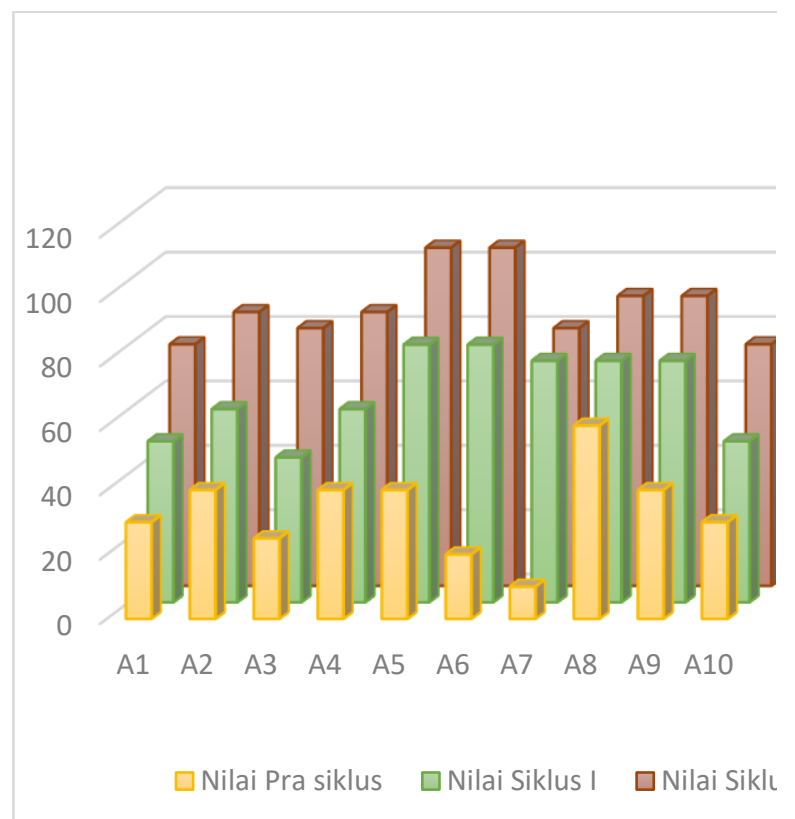

\section{Gambar 4. Perbandingan Nilai Prasiklus, Siklus I, dan Siklus \\ II}

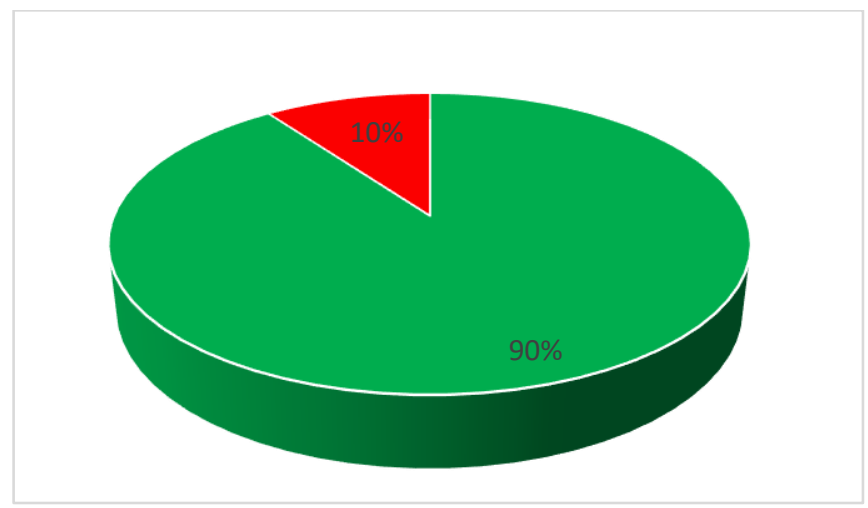

Gambar 5. Tabel Presentase Nilai kemampuan berfikir kritis Diatas Nilai 80 pada siklus II

\section{Tahap Refleksi}

Berdasarkan temuan-temuan dalam pelaksanaan tindakan siklus II, dapat disimpulkan bahwa penerapan model inkuiri terbimbing berbasis fenomena alam dapat meningkatkan kemampuan berfikir kritis siswa kelas II SDN 4 Kecamatan Kedunggebang Banyuwangi. Hal ini ditunjukan dengan nilai pada gambar 5 dimana Nilai kemampuan berfikir kritis Diatas Nilai 80 pada siklus II mencapai $90 \%$.

Oleh karena itu, peneliti dan guru berpendapat bahwa proses dan hasil yang sudah dicapai pada tindakan siklus II ini sudah dapat dijadikan tolak ukur bagi keefektivan penerapan model inkuiri terbimbing berbasis fenomena alam untuk 
meningkatkan kemampuan berfikir kritis siswa kelas II SDN 4 Kecamatan Kedunggebang Banyuwangi.

\section{PENUTUP}

\section{Simpulan}

Penerapan model inkuiri terbimbing berbasis fenomena alam dapat meningkatkan kemampuan berfikir kritis siswa kelas II SDN 4 Kecamatan Kedunggebang Banyuwangi. Hal ini dapat ditunjukkan dari peningkatan hasil belajar siswa yang mengalami peningkatan atau ketuntasan sebagaimana indicator kesuksesan penelitian ini yaitu ketuntasan klasikal mencapai $100 \%$
Setelah dilaksanakan penelitian tindakan kelas dengan menggunakan model model inkuiri terbimbing berbasis fenomena alam, maka nilai hasil belajar siswa meningkat dari prasiklus hingga siklus 2 yaitu pada pra siklus nilai hasil belajar siswa memiliki rata-rata 33,5 dengan ketuntasan klasikal sebesar 0\%; sedangkan pada siklus 1 meningkat menjadi rata-rata 65 dengan ketuntasan klasikal sebesar 50\%; sedangkan pada siklus 2 telah mencapai indicator ketuntasan yaitu rata-rata 90 dengan ketuntasan klasikal sebesar $100 \%$.

\section{DAFTAR PUSTAKA}

Ajeyalemi, D. A. (1993). Teacher strategies used by exemplary sts teachers. what research says to the science teaching. Washington DC : National Science Teachers Association.

Alberta. (2004). Focus on inquiry: a teaclter's guide to based learning. Canada: Alberta Learning Centre.

Amin, M. (1987). Mengajarkan ilmu pengetahuan alam (ipa) dengan menggunakan metode "discovery" dan "inquiry", bagian 1. Jakarta: Depdikbud.

Aqib. (2011). Pendidikan karakter membangun perilaku positif anak bangsa. Yrama Widya: Bandung.

Arikunto, S. (2009). Dasar - dasar evaluasi pendidikan. Jakarta: Bumi Akasara.

Arends, R. (1997). Classroom instruction and management. New York. McGrrawhill Company, Inc.

Klentschy dan Thompson. (2008). Scaffolding science inquiry. United States of America: Heinemann 
Kuhlthau, C. (2012). Guided inquiry design: A Framework for inquiry in your school. Santa Barbara: ABC-CLIO LCC.

Larson Nippolt, Pamela \& Wang, Hui-Hui. (2010). Engaging youth in non-formal learning through experiential learning and inquiry-based learning methods. University of Minnesota.

Lee, Virginia. (2004). Teaching and learning through inquiry: a guidebook for institutions and instructors. Stylus Publising, lcc: Washington, D.C 